\title{
Translation and cross-cultural adaptation of "Trapeziometacarpal Arthrosis Symptoms and Disability-TASD" into Brazilian Portuguese
}

\author{
Vinícius Alexandre de Souza Almeida* (D), Carlos Henrique Fernandes (D), Lia Miyamoto Meireles(10, \\ Flavio Faloppa (1), Benno Ejnisman (1) and Moises Cohen (1)
}

\begin{abstract}
Background: Osteoarthritis is the most common form of hand arthritis and arthritis of the carpometacarpal joint of the thumb is a potentially limiting disease. There is no homogeneity in the evaluation of outcomes for the rhizarthrosis treatment. In an attempt to standardize the evaluation of results, some subjective questionnaires, non-specific, were used to evaluate rhizarthrosis. Trapeziometacarpal Arthrosis Symptoms and Disability (TASD) was described by Becker et al.with the purpose of evaluating symptom intensity and degree of disability, as to compare results after treatment. Our objective is to translate, validate and do the cultural adaptation of the questionnaire TASD into the Brazilian Portuguese.
\end{abstract}

Methods: The questionnaire was translated, with reverse translation. The translations were evaluated and synthesized by a committee, arriving at TASD-BR. Thirty-one patients with a diagnosis of rhizarthrosis answered the questionnaire. We evaluated, the internal consistency, reliability, agreement and ceiling and floor effect for validation.

Results: The questionnaires were translated and adapted according to defined protocols. The internal consistency, through Cronbach's a coefficient for TASD-BR, was 0.927. The questionnaire's reliability, through the Intraclass Correlation Coefficient, was also shown to be quite high, with $\mathrm{k}=0.961$ (0.954-0.967). The agreement, measured through the Standard Error Measurement, remained with standardized values below 5\%. There was no ceiling and floor effect.

Conclusion: Through specific methodology we consider TASD-BR translated and valid for the Brazilian Portuguese. Keywords: Osteoarthritis, Surveys and questionnaires, Translation, Carpometacarpal joints, Reproducibility of Results

\section{Background}

Osteoarthritis is the most common form of hand arthritis. It is a complex disorder that can be characterized in several subtypes such as interphalangeal arthrosis, nodular arthritis, erosive arthritis, and arthritis of the carpometacarpal joint of the thumb, or rhizarthrosis $[1,2]$.

The handgrip mechanism depends mainly on the thumb. For the performance of this movement, besides

*Correspondence: vinicius.asa@hotmail.com

Trauma and Orthopaedics Department, Federal University of Sao Paulo, São Paulo, Brazil the integrity and harmony of the tenar musculature, it is necessary to have adequate positioning and congruence of its joints, especially the carpometacarpal joint of the thumb [3].

Rhizarthrosis is a potentially limiting disease, which causes pain and decreases the capacity for work, leisure, physical activities, and daily activities with a consequent decrease in quality of life $[4,5]$. However, the patient's symptoms do not always correspond to the radiographic findings. Radiographic variation or ultrasound exams showing joint degeneration may not correspond to functional or inflammatory limitations. This original author(s) and the source, provide a link to the Creative Commons licence, and indicate if changes were made. The images or other third party material in this article are included in the article's Creative Commons licence, unless indicated otherwise in a credit line to the material. If material is not included in the article's Creative Commons licence and your intended use is not permitted by statutory regulation or exceeds the permitted use, you will need to obtain permission directly from the copyright holder. To view a copy of this licence, visit http://creativecommons.org/licenses/by/4.0/. 
can disturb the management and the indications of treatment $[1,6]$.

There is no homogeneity in the evaluation of outcomes for the rhizarthrosis treatment. In a systematic review, 316 papers were evaluated, which found 65 instruments for outcome measures after some type of treatment [7]. This lack of standardization of measuring instruments can be a bias in the evaluation of clinical outcomes, and perhaps for this reason, no evidence of the superiority of one treatment over another is found [8].

In an attempt to standardize the evaluation of results, some subjective questionnaires, non-specific, were used to evaluate rhizarthrosis, without much success $[7,8]$. We found in the literature three specific questionnaires for the evaluation of rhizarthrosis, all in English language. In 2007, the Nelson Score was described, which had little acceptance [9]. Also, specific to evaluate rhizarthrosis, the Thumb Disability Exam (TDX) questionnaire was described by Noback et al., with 20 questions [11]. At last, in 2016, Trapeziometacarpal Arthrosis Symptoms and Disability (TASD) was described by Becker et al.with the purpose of evaluating symptom intensity and degree of disability, as to compare results after treatment. It was the result of a summary done through information collected from doctors, patients and the literature. It was elaborated with 12 questions in 2 subdivisions, one of them with 7 items related to symptoms, and the other with 5 items related to the inability to perform activities [10].

The questions are answered considering what happened to the patient in the last two weeks. The "intensity of symptoms" was categorized on a scale of 1 (no symptoms) up to 5 (very intense symptoms), and the difficulty of performing activities was categorized on a scale of 1 (without difficulty) up to 5 (unable to do it), following the Likert scale [10]. The results obtained are transformed into a variable between 0 and 100, according the formula [10]:

$$
\text { Score }=\left(\frac{N}{Q-B}-1\right) * 25
$$

where $\mathrm{N}$ is the total sum, $\mathrm{Q}$ is the number of total questions and $B$ is the number of questions left blank, being a maximum of 2 to be considered valid. Thus, the higher the score, the greater the disability. This questionnaire are quick to fill out and easy to understand. In the original description, TASD showed good validity and reproducibility in relation to the specific symptoms and limitations of rhizarthrosis [10].

The translation and cultural adaptation process of questionnaires described in other languages is a common practice in the literature. The objective of this process is to make it possible to compare results through a homogeneous outcome, even in papers made in different cultural contexts [12]. Due to its characteristics, TDX has been translated and validated into Portuguese but we didn't find previous translations for TASD, in any other languages $[11,13]$. Compared to TDX, the TASD questionnaire is easily and quickly for patients, therefore, the objective of this paper was to translate, do the cultural adaptation and validate the questionnaire "Trapeziometacarpal Arthrosis Symptoms and Disability Questionnarie (TASD)" into the Brazilian Portuguese.

\section{Methods}

This survey of translation, cultural adaptation and validation was carried out the postgraduate program in health sciences applied to sport and physical activity and at the hand surgery clinic at the University Hospital. The research was properly approved by the Research Ethics Committee. The authors of the original questionnaire authorized the translation process. All individuals who participated in the study filled out the informed consent form.

The translation and cultural adaptation were done following guidelines of Beaton et al. [14]. Initially, the translation into Brazilian Portuguese was done by two independent translators, one specialist in the medical field and the other specialist in languages. Both with Brazilian Portuguese as their native language. Two translations were achieved: T1 and T2. They were synthesized by an expert committee, reaching a T12 version in Brazilian Portuguese.

This T12 version was handed to two independent translators, different from the first ones, with English as their native language, and the reverse translation was done. So, we come to two reverse translations: BT1 and BT2. The experts committee composed of translators, orthopedists and physiotherapists, reviewed all documents, resolving discrepancies by consensus. The pre-test version of TASD-BR was completed.

The research was carried out using medical records of patients who were diagnosed with rhizarthrosis but had not been submitted to any surgical procedures between 2014 and 2017. We obtained a total of 69 patients, of whom 12 were excluded because of other pre-existing hand and wrist disorders. Out of the remaining 57 patients, 22 were excluded for not attending to phone calls and further 2 patients were excluded for declining to participate in a retest which was to be performed between 2 and 4 weeks after the first test. We therefore remained with 31 patients for the study. Out of these, 15 
patients had a bilateral while 16 had a unilateral involvement, totaling 46 assessed hands.

The printed pre-test questionnaire was applied to the patients and completed without assistance. For patients with low education, the researcher, without direct interference, performed a reading. The same researcher made all the applications. The re-test was applied after 2 to 4 weeks, by e-mail or telephone contact, having the same researcher reading and filling out the questionnaire. In patients with bilateral disease, the questionnaire was performed for each hand.

\section{Statistical analysis}

The questionnaire validation process was done with the calculation of the psychometric variables. Internal consistency, a measure of the homogeneous relation of the items in the questionnaire, was calculated using Cronbach's $\alpha$ coefficient for each of the items, with $\alpha \geq 0.70$, as described by Streiner and Norman [15]. The ceiling and floor effect was considered when more than $15 \%$ of the interviewers reached the maximum (scored 95 or more) or minimum score (scored 5 or less). If this effect occurs, it is a sign of low content validity, and can unite different individuals in the same group, also harming reliability and responsiveness.

Reliability was assessed using the intraclass correlation coefficient (ICC) obtained through the test and re-test. We used the correlation classification scale according to Landis and Koch, through Cohen's kappa coefficient, $\kappa$, in which there is a variation from -1 to 1 , where 1 means total agreement, -1 means total disagreement and zero means randomness [16]. Agreement was assessed using the standard error of measurement (SEM), which reflects the instrument intrinsic error. The SEM is calculated as the standard deviation of the differences between the scores of the two test and re-test sessions, divided by the square root of $2[17,18]$. Construct Validity measures the relation of a new instrument with other instruments that theoretically assess similar hypotheses and concepts. It was verified by means of the linear correlation coefficient between Spearman ordinal variables in the translated questionnaires Trapeziometacarpal Arthrosis Symptoms and Disability (TASD-BR) and the Thumb Disability Exam (TDX-BR), considering good validity when the $\rho \geq 0.7$ coefficient $[15,17,18]$.

The relation between the final score and the involvement of the dominant member was verified. The comparison was done using a paired $t$ test. Correlations or significant differences were considered to be those in which the $p$ value found was less than or equal to 0.05 [15].

\section{Results}

The questionnaire was applied to 31 patients, 29 answered the printed questionnaire individually and two patients with low education had the questionnaire read by a researcher. A total of 15 patients had bilateral involvement, and answered a questionnaire for each of the thumbs. A total of 46 questionnaires were taken.

In the population studied, $83.9 \%$ were women, $48.4 \%$ had the disease bilaterally, $32.2 \%$ only on the left and $19.4 \%$ only on the right. However, $90.3 \%$ had the right hand as dominant. Regarding the time of symptom beginning, $21.8 \%$ had symptoms less than 2 years, $43.4 \%$ between 2 and 10 years, and $34.8 \%$ more than 10 years.

The results of internal consistency, ceiling and floor effects, agreement and reliability are shown in Table 1. For the questionnaire, and even when separated by subdivisions "symptoms" and "ability to perform activities", high internal consistency was found $(\alpha>0.70)$, ceiling and floor notable effect were not observed, high confidence $(\kappa>0.60)$, and the agreement was considered as good $(<10 \%)$ or very good $(<5 \%)[15,17,18]$.

The construct validity was also shown to be high $(\rho=0.893, p<0.001)$. Comparing the TASD-BR with the TDX-BR, previously translated, they demonstrate a linear relation, according to the dispersion graph in Fig. 1.

In 46 evaluated hands, $54.3 \%$ were non-dominant hands and $45.7 \%$ were dominant hands. The fact that the disease affects the dominant or non-dominant hand did not cause significant differences $(t=0.34 ; p=0.736)$ (Fig. 2).

Patient related difficulties in completing the questionnaires, and the patients fill out once, without limit of

Table 1 Internal consistency, Floor and ceiling effects, reliability and agreement for the TASD questionnaire $(n=46)$

\begin{tabular}{lllll}
\hline & Cronbach's a & Floor/ceiling (in \%) & ICC $-\mathbf{k}($ IC95\%) & (SEM in \%) $^{\mathbf{b}}$ \\
\hline TASD & 0.927 & $4.3 \% / 0 \%$ & $0.961(0.954-0.967)$ & 3.87 \\
Symptoms & 0.919 & $2.2 \% / 0 \%$ & $0.966(0.957-0.972)$ & 3.68 \\
Ability to perform activities & 0.847 & $6.5 \% / 2.2 \%$ & $0.955(0.942-0.965)$ & 5.49 \\
\hline
\end{tabular}

a Percentage of scores less than 5 or greater than 95

${ }^{\mathrm{b}}$ ICC_-Intraclass Correlation Coefficient

'SEM-Standard Error of Measurement 


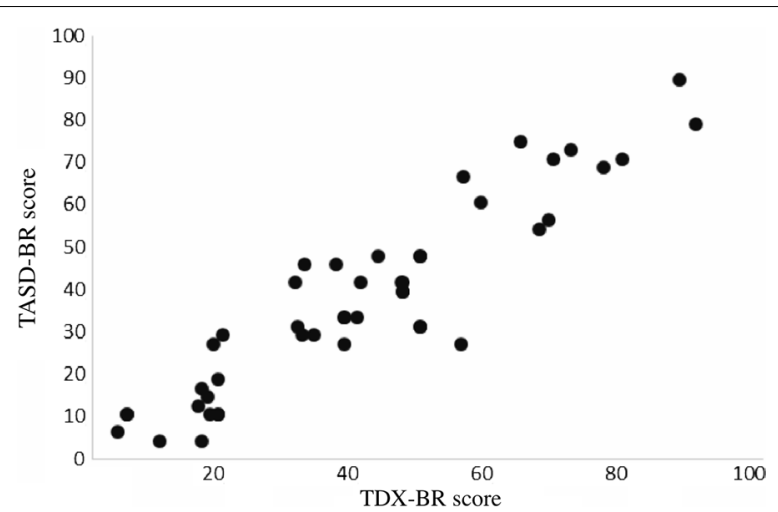

Fig. 1 Correlation between the patients'scores on the TDX-BR and TASD-BR questionnaires

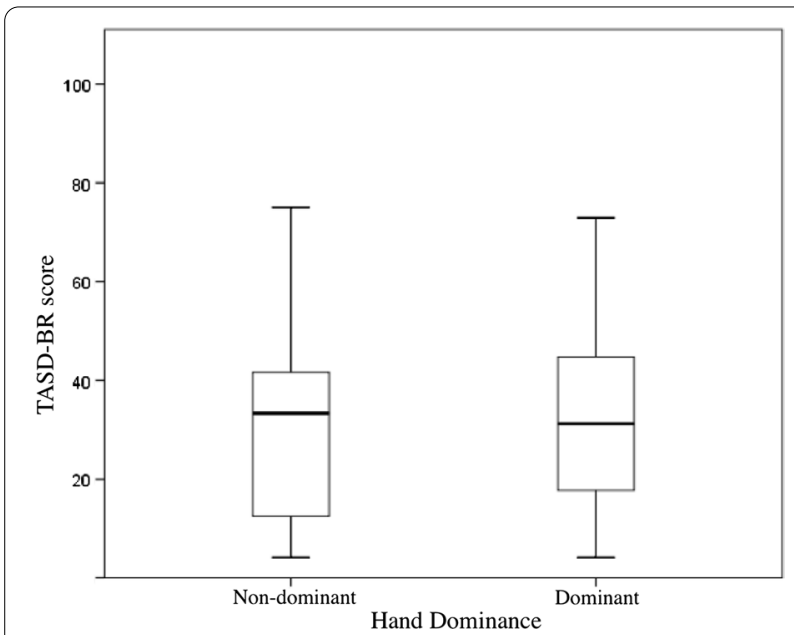

Fig. 2 Box diagram for TASD-BR score, in relation to the dominant or non-dominant hand

time or prior verification. All patients evaluated considered the questions clear and easy to understand. So the experts committee decided to not change the pre-test version and we concluded the final version of TASD-BR (Fig. 3).

\section{Discussion}

The diagnosis of rhizarthrosis is based on clinical signs and symptoms confirmed by imaging exams. The clinical condition of rhizarthrosis is characterized by progressive pain, limitation of pinch activities involving the thumb, edema at the base of the thumb, apparent angular deviation and crackling [19]. However, Baker et al. in reviewing the evidence-based literature observed that most of the patients with radiological images of rhizarthrosis are asymptomatic. The alterations found in the imaging exams do not always correspond to the clinical condition presented, that means, patients with typical alterations in the imaging exam may have mild symptoms or even be asymptomatic [20, 21].

Self-assessment questionnaires have been used in the literature to evaluate treatment results for different health problems. The translation and cultural adaptation to Brazilian Portuguese makes it possible to use these instruments in Brazil [22-24]. In search for a more specific tool, questionnaires have been described to evaluate the pain intensity and the functional limitation caused by rhizarthrosis. In 2007, the Nelson Score was described, which presents 10 questions about daily activities of living, with the objective of evaluating the surgical results of rhizarthrosis [9]. In 2016, the Thumb Disability Exam (TDX) was described, which consists of 20 questions. During the translation and validation process, it was considered reproducible for Brazilian Portuguese (TDX$\mathrm{BR})$, although difficulties in understanding some questions have been described, according to the translators [13]. In the description of the TASD, Becker et al.considered to be a simple and self-administered scoring system and was considered concise and useful in the evaluating of symptoms and disability related to rhizarthrosis [20]. In our paper, the application of the translated and validated TASD-BR to patients did not present any difficulty in understanding. We consider this questionnaire to be more concise and simpler, even though it maintains a good linear correlation with the TDX-BR. The time to complete the questionnaire was not measured, but because there are eight questions less than the TDX-BR, we deduce to be shorter.

Following the recommendations of Matsuo et al., we chose to keep the page in vertical format, as it facilitates understanding in the Brazilian socio-cultural context [25].

The method used to apply this questionnaire should be considered as a limitation factor. The first application was done personally with all the patients. The second application was carried out through telephone or e-mail contacts. We only had personal interviews with 2 patients who did not know how to read. This is used to prevent social exclusion of patients due to low education levels which could lead to reduction of the sample $[26,27]$. Furthermore, many patients had financial limitations to move back to the hospital to a new evaluation. Since we never experienced or witnessed any difficulty in understanding the questionnaire during the first application, we considered that the second method of data collection could not result in significant results discrepancy.

For the TASD-BR questionnaire, and even when separated by subdivisions "symptoms" and "ability to perform activities", high internal consistency was found, 
TASD-BR: Responda o Questionário com apenas uma alternativa:

\section{Por favor, diga a intensidade dos} seguintes sintomas:

1. Você sente dor na base dos seu polegar (próximo ao punho), sem atividades (mesmo quando não mexe o polegar)?
1. NENHUMA
2. LEVE
3. MODERADA
4. INTENSA
5. MUITO INTENSA

2. Você sente dor na base dos seu polegar (próximo ao punho) durante atividades (quando mexe o polegar)?
1. NENHUMA
2. LEVE
3. MODERADA
4. INTENSA
5. MUITO INTENSA

3. Você sente desconforto (incômodo) na base do polegar (próximo ao punho) quando aperta ou encosta em alguma coisa?
1. NENHUM
2. LEVE
3. MODERADO
4. INTENSO
5. MUITO INTENSO

4. Você percebe inchaço (edema) na base do polegar (próximo ao punho)?
1. NENHUM
2. LEVE
3. MODERADO
4. INTENSO
5. MUITO INTENSO

5. Você percebe Rigidez (endurecimento) na base do polegar (próximo ao punho) quando faz algum movimento?
1. NENHUM (A)
2. LEVE
3. MODERADO (A)
4. INTENSO (A)
5. MUITO INTENSO (A)

6. Quanto você perdeu de movimento do polegar?
1. NENHUM
2. LEVE
3. MODERADO
4. INTENSO
5. MUITO INTENSO

7. Você sente diminuição de força quando pega e segura algum objeto?
1. NENHUMA
2. LEVE
3. MODERADA
4. INTENSA
5. MUITO INTENSA

\section{Por favor avalie quanta dificuldade você tem ao fazer as seguintes atividades:}

1. Abrir um pote ou garrafa com tampa de rosca apertada ou nova
1. SEM DIFICULDADE
2. UM POUCO DE DIFICULDADE
3. DIFICULDADE MODERADA
4. MUITA DIFICULDADE
5. NÃO CONSEGUE FAZER

2. Virar uma chave (de uma porta)
1. SEM DIFICULDADE
2. UM POUCO DE DIFICULDADE
3. DIFICULDADE MODERADA
4. MUITA DIFICULDADE
5. NÃO CONSEGUE FAZER

3. Girar a maçaneta redonda (do tipo bola) da porta
1. SEM DIFICULDADE
2. UM POUCO DE DIFICULDADE
3. DIFICULDADE MODERADA
4. MUITA DIFICULDAE
5. NÃO CONSEGUE FAZER

4. Fechar o zíper (fecho-ecler)
1. SEM DIFICULDADE
2. UM POUCO DE DIFICULDADE
3. DIFICULDADE MODERADA
4. MUITA DIFICULDAE
5. NÃO CONSEGUE FAZER

5. Segurar objetos grandes (copo, garrafa, livro, etc.)
1. SEM DIFICULDADE
2. UM POUCO DE DIFICULDADE
3. DIFICULDADE MODERADA
4. MUITA DIFICULDAE
5. NÃO CONSEGUE FAZER

Fig. 3 TASD-BR final version 
with $\alpha \geq 0.70$, and notable ceiling and floor effect were not observed. Internal consistency is the measurement property that assesses the ability of a questionnaire to measure a single concept using multiple items, or even evaluating it in subdivisions. Therefore, it is extremely important that this value is high, as they denote specificity in testing a construct.

We chose the interval of 2 to 4 weeks between the test and the re-test. This interval should be sufficient to avoid any change in symptoms or progression of the disease, neither for the patient to be able to remember the answers that he had answered in the previous questionnaire [18]. The questionnaire showed high reliability. Intraclass correlation coefficient (ICC) values greater than 0.60 are considered to be a good correlation. In our study, this value was $\kappa=0.961(0.954-0.967)$. These values denote a high correlation between test and retest and demonstrate that the questionnaire is reliable in reproducing symptoms.

Agreement, measured using the SEM, was considered to be good $(<10 \%)$ or very good $(<5 \%)$. The questionnaire had a high correlation between the test and the retest, with $\kappa=0.961(0.954-0.967)$. All variables maintained the same pattern when compared to the original questionnaire $[10,17,18]$.

Construct Validity measures the relation of a new instrument with other instruments that theoretically assess similar hypotheses and concepts. As there was no description of a specific gold standard questionnaire for rhizarthrosis, the original TASD questionnaire maintained a linear correlation with The Disabilities of Arm Shoulder and Hand Score (DASH), Patient Health Questionnaire-9 (PHQ9) and Pain Self Efficacy Questionnaire (PSEQ) $[10,14]$. In our research, the construct validity was measured by the correlation between the results of the TDX-BR questionnaire, previously translated [13]. A linear relation was found between the two questionnaires. This means that high scores on the TDX-BR must correlate with high scores on the TASD-BR, and vice versa. This correlation denotes efficiency in the two scores in measuring the same construct $[15,17,18]$.

Although the disease was more prevalent in the nondominant hand, the difference was not significant, and no correlation was found in the TASD-BR scores considering that. Thus, we conclude that this fact should not be considered as bias.

\section{Conclusion}

We consider the TASD questionnaire as translated into Brazilian Portuguese. The TASD-BR version is valid. Following consolidated guidelines, we have an objective instrument, which can be used in research related to rhizarthrosis in Brazil, in evaluating outcomes or diagnoses, with no need for authorization from the authors or training to apply.

\section{Abbreviations}

TASD: Trapeziometacarpal Arthrosis Symptoms and Disability; TASD-BR: Portuguese version of Trapeziometacarpal Arthrosis Symptoms and Disability; TDX: Thumb Disability Exam; ICC: Intraclass correlation coefficient; SEM: Standard error of measurement; TDX-BR: Portuguese version of Thumb Disability Exam; DASH: The Disabilities of Arm Shoulder and Hand Score; PHQ9: Patient Health Questionnaire-9; PSEQ: Pain Self Efficacy Questionnaire.

\section{Acknowledgements}

Not applicable

\section{Authors' contributions}

VASA did the interviews and applied the questionnaires to the participants, and was the major contributor in writing the manuscript. VASA, CHF and LMM where part of the experts committee. All authors read and approved the final manuscript

Funding

The authors declare that they have no funding.

\section{Availability of data and materials}

The data that support the findings of this study are available on request from the corresponding author VASA. The data are not publicly available due to them containing information that could compromise research participant.

\section{Declarations}

Ethics approval and consent to participate

The research was approved in the Research Ethics Comitte under certificate CAAE 80666617.4.0000.5505. The work was authorized by the researchers of the original questionnaire. All individuals filled out the informed consent form.

\section{Consent for publication}

Not Applicable.

\section{Competing interests}

The authors declare that they have no competing interests.

Received: 19 May 2021 Accepted: 17 September 2021

Published online: 09 October 2021

\section{References}

1. Güven N, Dinçer F, Çetin A, et al. Hand strenght and dexterity in interphalangeal hand osteoarthritis and effects of osteophyte formations. Adv Rheumatol. 2020. https://doi.org/10.1186/s42358-020-00143-7.

2. Sacilotto NDC, Giorgi RDN, Vargas-Santos AB, et al. Real-rheumatoid arthritis in real life-study cohort: a sociodemographic profile of rheumatoid arthritis in Brazil. Adv Rheumatol. 2020. https://doi.org/10.1186/ s42358-020-0121-5.

3. Hume MC, Gellman H, McKellop H, et al. Functional range of motion of the joints of the hand. J Hand Surg. 1990;15A(2):240-3.

4. Spaans AJ, Van Minnen LP, Kon M, et al. Conservative treatment of thumb base osteoarthritis: a systematic review. J Hand Surg. 2015;40(1):16-21.

5. Model Z, Liu AY, Kang L, et al. Evaluation of physical examination tests for thumb basal joint osteoarthritis. HAND. 2016;11(1):108-12.

6. Siviero P, Zambon S, Limongi F, et al. How hand osteoarthritis, comorbidity, and pain interact to determine functional limitation in older people: observations from the European Project on OSteoArthritis Study. Arthritis Rheumatol. 2016:68(11):2662-70.

7. Marks M, Schoones JW, Kolling C, et al. Outcome measures and their measurement properties for trapeziometacarpal osteoarthritis: a systematic literature review. J Hand Surg (European Volume). 2013;38(8):822-38. 
8. Visser AW, Boyesen P, Haugen IK, et al. Instruments measuring pain, physical function, or Patient's global assessment in hand osteoarthritis: a systematic literature search. J Rheumatol. 2015. https://doi.org/10.3899/ jrheum.141228.

9. Citron N, Hulme CE, Wardle N. A self-administered questionnaire for basal osteoarthritis of the thumb. J Hand Surg (European Volume). 2007:32(5):524-8.

10. Becker SJ, Teunis T, Ring D, et al. The trapeziometacarpal arthrosis symptoms and disability questionnaire: development and preliminary validation. HAND. 2016;11(2):197-205.

11. Noback PC, Lombardi JM, Seetharaman M, et al. Development and validation of a disease-specific questionnaire for basal joint arthritis. J Wrist Surg. 2017;6(02):126-33.

12. Guillemin F, Bombardier C, Beaton D. Cross-cultural adaptation of health-related quality of life measures: literature review and proposed guidelines. J Clin Epidemiol. 1993;46(12):1417-32.

13. Almeida VAS, Fernandes $\mathrm{CH}$, Meireles LM, et al. Tradução e adaptação cultural do questionário "Thumb Disability Exam-TDX" para o português brasileiro. Revista Brasileira de Ortopedia. 2020. https://doi.org/10.1055/s0040-1715508.

14. Beaton DE, Bombardier C, Guillemin F, Ferraz MB. Guidelines for the process of cross-cultural adaptation of self-report measures. Spine. 2000;25:3186-91.

15. Norman GR, Streiner DL. Biostatistics: the bare essentials. Shelton: PMPHUSA; 2008.

16. Landis JR, Koch GG. The measurement of observer agreement for categorical data. Biometrics. 1977. https://doi.org/10.2307/2529310.

17. Terwee CB, Bot SD, de Boer MR, et al. Quality criteria were proposed for measurement properties of health status questionnaires. J Clin Epidemiol. 2007;60(1):34-42.

18. Da Cunha RA, Hazime FA, da Silva Martins MC, et al. Translation, crosscultural adaptation, and clinimetric testing of instruments used to assess patients with ankle sprain in the brazilian population. J Orthop Sports Phys Ther. 2016;46(12):1042-50.
19. Baker RH, Al-Shukri J, Davis TR. Evidence-based medicine: thumb basal joint arthritis. Plast Reconstr Surg. 2017;139(1):256e-66e.

20. Ladd AL, Messana JM, Berger AJ, et al. Correlation of clinical disease severity to radiographic thumb osteoarthritis index. J Hand Surg. 2015;40(3):474-82.

21. Becker SJ, Bruinsma WE, Guitton TG, et al. Interobserver agreement of the Eaton-Glickel classification for trapeziometacarpal and scaphotrapezial arthrosis. J Hand Surg. 2016;41(4):532-40.

22. Azevedo PM, Sanson ES, Skare TL, et al. The Brazillian version of the hand mobility in scleroderma (HAMIS) test: translation and validation. Adv Rheumatol. 2019. https://doi.org/10.1186/s42358-019-0093-5.

23. Carvalho GRD, Oliveira EAD, Rocha VTM, et al. Cross-cultural adaptation and reliability of the pain response to activity and position questionnaire. Adv Rheumatol. 2019. https://doi.org/10.1186/s42358-019-0098-0.

24. De Paula Costa RM, Cardinot TM, Mathias LNCDC, et al. Validation of the Brazilian version of the hip outcome score (HOS) questionnaire. Adv Rheumatol. 2018;58(1):1-8.

25. Matsuo RP, Fernandes CH, Meirelles LM, et al. Translation and cross-cultural adaptation of the 6-item Carpal Tunnel Syndrome Symptoms Scale and Palmar Pain Scale Questionnaire Into Brazilian Portuguese. Hand NY. 2016;11(2):168-72.

26. Fernandes $\mathrm{CH}$, Neto JR, Meirelles LM, et al. Translation and cultural adaptation of the Brief Michigan Hand Questionnaire to Brazilian Portuguese language. HAND. 2014;9(3):370-4.

27. Oku EC, Andrade AP, Stadiniky SP, et al. Translation and cultural adaptation of the Modified-University of California at Los Angeles Shoulder Rating Scale to portuguese language. Rev Bras Reumatol. 2006;46(4):246-52.

\section{Publisher's Note}

Springer Nature remains neutral with regard to jurisdictional claims in published maps and institutional affiliations.
Ready to submit your research? Choose BMC and benefit from:

- fast, convenient online submission

- thorough peer review by experienced researchers in your field

- rapid publication on acceptance

- support for research data, including large and complex data types

- gold Open Access which fosters wider collaboration and increased citations

- maximum visibility for your research: over $100 \mathrm{M}$ website views per year

At BMC, research is always in progress.

Learn more biomedcentral.com/submissions 